\title{
Prevalence of nodal involvement in rectal cancer after chemoradiotherapy
}

Citation for published version (APA):

Haak, H. E., Beets, G. L., Peeters, K., Nelemans, P. J., Valentini, V., Rodel, C., Kuo, L., Calvo, F. A., Garcia-Aguilar, J., Glynne-Jones, R., Pucciarelli, S., Suarez, J., Theodoropoulos, G., Biondo, S., Lambregts, D. M. J., Beets-Tan, R. G. H., \& Maas, M. (2021). Prevalence of nodal involvement in rectal cancer after chemoradiotherapy. British Journal of Surgery, 108(10), 1251-1258.

https://doi.org/10.1093/bjs/znab194

Document status and date:

Published: 01/10/2021

DOI:

10.1093/bjs/znab194

Document Version:

Publisher's PDF, also known as Version of record

Document license:

Taverne

Please check the document version of this publication:

- A submitted manuscript is the version of the article upon submission and before peer-review. There can be important differences between the submitted version and the official published version of record.

People interested in the research are advised to contact the author for the final version of the publication, or visit the DOI to the publisher's website.

- The final author version and the galley proof are versions of the publication after peer review.

- The final published version features the final layout of the paper including the volume, issue and page numbers.

Link to publication

\footnotetext{
General rights rights.

- You may freely distribute the URL identifying the publication in the public portal. please follow below link for the End User Agreement:

www.umlib.nl/taverne-license

Take down policy

If you believe that this document breaches copyright please contact us at:

repository@maastrichtuniversity.nl

providing details and we will investigate your claim.
}

Copyright and moral rights for the publications made accessible in the public portal are retained by the authors and/or other copyright owners and it is a condition of accessing publications that users recognise and abide by the legal requirements associated with these

- Users may download and print one copy of any publication from the public portal for the purpose of private study or research.

- You may not further distribute the material or use it for any profit-making activity or commercial gain

If the publication is distributed under the terms of Article $25 \mathrm{fa}$ of the Dutch Copyright Act, indicated by the "Taverne" license above, 


\title{
Prevalence of nodal involvement in rectal cancer after chemoradiotherapy
}

\author{
H. E. Haak ${ }^{1,2}$, G. L. Beets (D) ${ }^{1,2}$, K. Peeters ${ }^{3}$, P. J. Nelemans ${ }^{4}$, V. Valentini ${ }^{5}$, C. Rödel ${ }^{6}$, L. Kuo ${ }^{7}$, F. A. Calvo ${ }^{8}$, J. Garcia-Aguilar ${ }^{9}$, \\ R. Glynne-Jones ${ }^{10}$, S. Pucciarelli (ID) ${ }^{11}$, J. Suarez ${ }^{12}$, G. Theodoropoulos ${ }^{13}$, S. Biondo (ID ${ }^{14,15}$, D. M. J. Lambregts ${ }^{16}$, R. G. H. Beets-Tan ${ }^{2,16}$ \\ and M. Maas (iD) 16,*
}

\author{
${ }^{1}$ Department of Surgical Oncology, Netherlands Cancer Institute, Amsterdam, the Netherlands \\ ${ }^{2}$ GROW School for Oncology and Developmental Biology, Maastricht University, Maastricht, the Netherlands \\ ${ }^{3}$ Department of Surgery, Leiden University Medical Centre, Leiden, the Netherlands \\ ${ }^{4}$ Department of Epidemiology, Maastricht University Medical Centre, Maastricht, the Netherlands \\ ${ }^{5}$ Department of Radiation Oncology, Universita Cattolica del Sacro Cuore, Rome, Italy \\ ${ }^{6}$ Department of Radiation Oncology, Universitätsklinikum Frankfurt, Frankfurt, Germany \\ ${ }^{7}$ Department of Colorectal Surgery, Taipei Medical University Hospital, Taipei, Taiwan \\ ${ }^{8}$ Department of Oncology, General University Hospital Gregorio Marañón, Madrid, Spain \\ ${ }^{9}$ Department of Surgery, Memorial Sloan Kettering Cancer Centre, New York, USA \\ ${ }^{10}$ Department of Clinical Oncology, Mount Vernon Hospital, London, UK \\ ${ }^{11}$ Department of Surgical, Oncological and Gastroenterological Sciences, First Surgical Clinic, University of Padua, Padua, Italy \\ ${ }^{12}$ Department of Surgery, Hospital de Navarra, Pamplona, Spain \\ ${ }^{13}$ First Department of Propaedeutic Surgery, Athens Medical School, Hippocration General Hospital, Athens, Greece \\ ${ }^{14}$ Department of Surgery, Bellvitge University Hospital, Barcelona, Spain \\ ${ }^{15}$ IDIBELL, University of Barcelona, Barcelona, Spain \\ ${ }^{16}$ Department of Radiology, Netherlands Cancer Institute, Amsterdam, the Netherlands \\ Presented to the Annual Meeting of the American Society of Colon and Rectal Surgeons, June 2012, San Antonio, Texas, USA; published in abstract form as Dis Colon \\ Rectum 2012;55:e198
}

*Correspondence to: Department of Radiology, Netherlands Cancer Institute, PO Box 90203, 1006 BE Amsterdam, The Netherlands (e-mail: moniquemaas@live.nl)

\begin{abstract}
Background: The purpose of this study was to investigate the prevalence of ypN+ status according to ypT category in patients with locally advanced rectal cancer treated with chemoradiotherapy and total mesorectal excision, and to assess the impact of ypN+ on disease recurrence and survival by pooled analysis of individual-patient data.

Methods: Individual-patient data from 10 studies of chemoradiotherapy for rectal cancer were included. Pooled rates of ypN+ disease were calculated with 95 per cent confidence interval for each ypT category. Kaplan-Meier and Cox regression analyses were undertaken to assess influence of ypN status on 5-year disease-free survival (DFS) and overall survival (OS).

Results: Data on 1898 patients were included in the study. Median follow-up was 50 (range 0-219) months. The pooled rate of ypN+ disease was 7 per cent for ypT0, 12 per cent for ypT1, 17 per cent for ypT2, 40 per cent for ypT3, and 46 per cent for ypT4 tumours. Patients with ypN + disease had lower 5-year DFS and OS (46.2 and 63.4 per cent respectively) than patients with ypN0 tumours (74.5 and 83.2 per cent $)(P<0.001)$. Cox regression analyses showed ypN+status to be an independent predictor of recurrence and death.

Conclusion: Risk of nodal metastases (ypN+) after chemoradiotherapy increases with advancing ypT category and needs to be considered if an organ-preserving strategy is contemplated.
\end{abstract}

\section{Lay summary}

When patients are diagnosed with rectal cancer and the tumour grows beyond the rectal wall there is a high risk that the tumour has spread to nearby lymph nodes. This study showed that this relationship between tumour invasion depth and lymph node involvement is similar after treatment with (chemo)radiotherapy. Patients who have tumour cells remaining in the lymph nodes after (chemo) radiotherapy have a worse prognosis than patients who do not have cancer cells remaining in the lymph nodes. When an organ-preserving treatment is considered as an alternative therapy, this should be kept in mind during patient counselling.

\section{Introduction}

Total mesorectal excision (TME) and neoadjuvant (chemo) radiotherapy have improved rectal cancer treatment $t^{1,2}$ by reducing local failure rates. Neoadjuvant therapy may also facilitate organ-preservation strategies, whereby adequate local control may be achieved without the morbidity and 
quality-of-life implications associated with surgery ${ }^{3-5}$. For patients with a good response but a small residual lesion, some believe that local excision of the residual disease is appropriate, provided that regional lymph nodes have been sterilized with chemoradiotherapy ${ }^{6,7}$.

In primary early rectal cancer, the baseline tumour characteristics ( $\mathrm{T}$ category) can be used to estimate the risk of lymph node metastases (N status). This helps both the selection of patients for primary treatment by local excision and in the decision whether or not to perform a completion TME after local exci$\operatorname{sion}^{8-14}$. The same strategy could be used for patients with a small residual tumour after chemoradiotherapy, but fewer data are available regarding the prevalence of ypN+ among small residual lesions in patients with a locally advanced tumour at baseline. Overall, ypN+ rates reported in the literature vary from 0 to 11 per cent for ypT1 disease, 8 to 29 per cent for ypT2 disease, and 37 to 40 per cent for ypT3 disease ${ }^{15-17}$. To gain more insight into the risk of ypN+ status in locally advanced rectal cancer, this study investigated the prevalence of ypN+ according to ypT category in patients with locally advanced rectal cancer treated with chemoradiotherapy and TME, by pooled analysis of individual-patient data.

\section{Methods}

Patient data were selected from a data set that was used for a pooled meta-analysis of individual-patient data examining the prognostic significance of a complete response after chemoradiotherapy for patients with locally advanced cancer ${ }^{18}$. As the study contained data from previously published studies, no ethics approval or patient consent was needed. In total, 14 studies were included in the original study by Maas and colleagues ${ }^{18}$, of which $10^{19-28}$ could be included in the present analysis. One study was excluded because only patients with ypNO disease were included, two were excluded because of missing data on ypT categories (other than ypT0 versus ypT+) or missing information on receipt of adjuvant chemotherapy, and the author of another study declined participation for this analysis. The data from previous studies were combined into a single data set. The data comprised patient characteristics, baseline staging data, treatment details, histological data, and follow-up details.

\section{Statistical analysis}

The frequency of ypN+ status according to ypT category was calculated for each study, and pooled for all studies with 95 per cent confidence intervals by use of a random-effects model. To stabilize the variance of the proportions from individual studies, Freeman-Tukey arcsine square root transformation of the proportion with ypN+ status was used ${ }^{29}$. The transformed proportions were pooled using a DerSimonian and Laird random-effects model to account for heterogeneity among studies $^{30}$. Heterogeneity was quantified by the $\mathrm{I}^{2}$ index and Cochran's $Q$ test $^{31}$. For comparison of the 5 -year cumulative probability of local and distant recurrence, as well as diseasefree survival (DFS) and overall survival (OS) between patients with ypN+ and ypNO status, Kaplan-Meier analysis and Cox proportional hazards models stratified by study were used. For these time-to-event analyses, follow-up started on the day of surgery and ended on the day of disease relapse or death or day of last follow-up. Patients were censored if, by the end of the follow-up period, they had not developed the outcome of interest or were lost to follow-up. The log rank test was used to compare Kaplan-Meier curves. The Cox proportional hazards assumption was tested on the basis of Schoenfeld residuals after fitting a model and by visual inspection of log minus log plots. The proportional hazards assumption is not violated if the proportionality test is not significant and the plots show that the survival curves for the groups being compared run parallel to each other. $P \leq 0.050$ was considered statistically significant. Analyses were performed using StatsDirect ${ }^{\circledR}$ software (StatsDirect, Altrincham, UK).

\section{Results}

Patient and treatment characteristics for each study are shown in Table 1 and Table S1. The imaging technique used for clinical staging varied between studies; it mainly consisted of endorectal ultrasonography and CT, with additional MRI in some studies. A total of 2026 patients were included in the data sets of the original 10 selected studies, of whom 128 were excluded owing to unknown ypT or ypN category. Therefore, 1898 patients were included in the present analyses. Survival data were available for 1856 patients. All studies used external beam radiotherapy in doses ranging from 45 to 50.4 Gy in 25-28 fractions. The interval between chemoradiotherapy and surgery was most commonly 6-8 weeks. Chemotherapy using 5-fluorouracil was administered as a radiosensitizer in the majority of patients. Most patients also received adjuvant chemotherapy (5-FU-based); the type of adjuvant therapy was unknown for two studies.

Of all 1795 patients with available data on CT category, 1708 (95.1 per cent) were diagnosed with CT3-4 disease before neoadjuvant treatment. Data on cN status were available for 1802 patients, of whom 1080 (59.9 per cent) had cN+ disease, whereas only 26.2 per cent had ypN+ disease at histological examination of the resection specimen. Median follow-up was 50 (range 0-219) months.

The pooled rate of ypN+ disease was 7 (95 per cent c.i. 3 to 12) per cent for ypT0 ( $I^{2}=56$ per cent; $\left.P=0.015\right), 12$ (4 to 24) per cent for ypT1 ( $I^{2}=53$ per cent; $\left.P=0.025\right), 17$ (12 to 23 ) per cent for ypT2 ( $I^{2}=62$ per cent; $\left.P=0.005\right), 40$ (36 to 44$)$ per cent for ypT3 ( $I^{2}=32$ per cent; $\left.P=0.154\right)$, and 46 (34 to 57) per cent for ypT4 $\left(I^{2}=0\right.$ per cent; $\left.P=0.586\right)$ (Fig. 1$)$. Table 2 provides an overview of the proportion of patients with (y)pN+ disease according to (y)pT category after chemoradiotherapy in the present study, compared with rates reported in the literature for patients who did not receive neoadjuvant treatment.

\section{Long-term outcome}

Patients with ypN+ disease had a lower DFS and OS rates at 5 years than patients with ypNO disease (Fig. 2). Patients with cN+ tumours before chemoradiotherapy who had ypNO status after chemoradiotherapy had similar 5-year DFS to patients who had cNO lesions at primary staging and ypNO after chemoradiotherapy: 74.8 (95 per cent c.i. 72 to 78 ) and 73.7 (70 to 78) per cent respectively. cN status had limited accuracy, reflected by the large number of patients staged as cNO who had ypN+ disease after TME (156 of 722, 21.6 per cent). In addition, $\mathrm{cN}$ had only moderate predictive value for long-term DFS (hazard ratio (HR) 1.03, 95 per cent c.i. 0.84 to 1.28) and OS (HR 1.20, 0.94 to 1.54).

In the subgroup of patients with ypT0-2 disease, there was a difference in 5-year DFS between ypN+ and ypN0 groups: 65.0 (57 to 74$)$ and 81.3 (78 to 84$)$ per cent respectively $(P<0.001)$. Fiveyear OS rates also differed: 81.1 (73 to 88 ) versus 87.5 (85 to 90) per cent $(P=0.005)$. Additional survival analyses according to ypN status separated by ypT category are shown in Fig. S1. 
Table 1 Characteristics of included studies

\begin{tabular}{|c|c|c|c|c|c|c|c|}
\hline Reference & Population & $\begin{array}{l}\text { No. } \\
\text { of } \\
\text { patients }\end{array}$ & $\begin{array}{l}\text { Type of } \\
\text { neoadjuvant } \\
\text { treatment }\end{array}$ & $\begin{array}{l}\text { Interval } \\
\text { between } \\
\text { CRT and } \\
\text { surgery (weeks) }\end{array}$ & $\begin{array}{l}\text { Type of } \\
\text { adjuvant } \\
\text { chemotherapy }\end{array}$ & $\begin{array}{l}\text { Type of } \\
\text { study }\end{array}$ & $\begin{array}{l}\text { Clinical } \\
\text { staging } \\
\text { modality }\end{array}$ \\
\hline Valentini et al. ${ }^{22}$ & $\begin{array}{l}\text { LARC, } \\
\text { extraperitoneal, } \\
\text { T3-T4 or } \mathrm{N}+\end{array}$ & 474 & $\begin{array}{l}\text { External RT or IORT, } \\
\text { 5-FU + mitomycin } \\
\text { C/cisplatin }\end{array}$ & $6-8$ & 5-FU & Prospective & $\mathrm{EUS}+\mathrm{CT}$ \\
\hline Rödel et al. ${ }^{28}$ & Stage II-III & 348 & External RT, 5-FU & 6 & 5-FU & $\begin{array}{l}\text { Prospective } \\
\quad \text { (arm of RCT) }\end{array}$ & EUS + CT \\
\hline Kuo et al. ${ }^{26}$ & T3-T4 N+M0 & 242 & $\begin{array}{l}\text { External RT, 5-FU, } \\
\text { mitomycin C }\end{array}$ & $6-8$ & n.r. & Retrospective & MRI \\
\hline García-Aguilar et al. ${ }^{19}$ & Stage II-III & 154 & External RT, 5-FU & 6 & $\begin{array}{l}\text { 5-FU and } \\
\text { leucovorin }\end{array}$ & Retrospective & $\mathrm{EUS}+\mathrm{CT}$ \\
\hline Hughes et al. ${ }^{20}$ & T3-T4 & 147 & External RT, 5-FU & $6-12$ & n.r. & Prospective & $\mathrm{EUS}+\mathrm{CT}+\mathrm{MRI}$ \\
\hline Suárez et al. ${ }^{27}$ & LARC & 119 & External RT, 5-FU & 6 & n.r. & Retrospective & $\mathrm{CT}$ \\
\hline Díaz-González et al. ${ }^{21}$ & T3-4 N+ & 117 & $\begin{array}{l}\text { External RT/IORT, 5-FU } \\
\quad \text { or tegafur }\end{array}$ & $4-6$ & $\begin{array}{l}\text { 5-FU and } \\
\text { leucovorin }\end{array}$ & Prospective & EUS + CT \\
\hline Pucciarelli et al. ${ }^{23}$ & $\mathrm{~T} 3-4 \mathrm{~N}+\mathrm{M0}$ & 106 & $\begin{array}{l}\text { External RT, 5-FU + } \\
\text { leucovorin/ } \\
\text { carboplatin/oxaliplatin }\end{array}$ & $6-8$ & $\begin{array}{l}\text { 5-FU and } \\
\text { leucovorin }\end{array}$ & Retrospective & EUS + CT \\
\hline Biondo et al. $^{25}$ & T3-4 LARC & 103 & External RT, 5-FU & $6-8$ & $\begin{array}{l}\text { 5-FU and } \\
\text { leucovorin }\end{array}$ & Prospective & $\mathrm{CT}$ \\
\hline Theodoropoulos et al. ${ }^{24}$ & All & 88 & $\begin{array}{l}\text { External RT, 5-FU +/- } \\
\text { leucovorin }\end{array}$ & 6 & n.r. & Retrospective & $\mathrm{EUS}+\mathrm{CT}$ \\
\hline
\end{tabular}

Adapted from Maas et al. ${ }^{18}$. CRT, chemoradiotherapy; LARC, locally advanced rectal cancer; N+, clinically node-positive; RT, radiotherapy; IORT, intraoperative radiotherapy; 5-FU, 5-fluorouracil; EUS, endorectal ultrasonography; n.r., not reported.

In a multivariable Cox regression model, stratified by centre (including sex, age, cT, cN, distance from anal verge, type of surgery, ypT, and chemotherapy as independent variables), ypN+ status was a predictor of recurrence and death, with HRs of 2.45 (1.70 to 3.54) and 2.05 (1.28 to 3.29) for DFS and OS respectively in the subgroup of patients with ypT0-2 (Table 3), but also in the total patient group (Table 4).

\section{Discussion}

This study has shown that the pooled prevalence of lymph node metastases after neoadjuvant chemoradiotherapy in patients with locally advanced rectal cancer increases with increasing depth of residual tumour, and is in the same range as that for non-irradiated tumours. With a tumour complete response (ypT0) there is still a 7 per cent risk of lymph node metastases. In this setting, the presence of lymph node metastases is a strong predictor of poor long-term outcome, as for non-irradiated tumours.

The findings of this study are in accordance with previous reports. Generally, rates of lymph node metastases in patients with ypT0 disease are below 10 per cent in most studies ${ }^{15,32,33}$. In ypT2 tumours, lymph node metastases have been reported in up to 29 per cent of patients ${ }^{15,16}$, which is higher than the 17 per cent in the present study. However, the GRECCAR 2 trial $^{17}$ reported a much lower incidence of nodal involvement of 8 per cent, which may be explained by differences in the study population as the GRECCAR 2 trial included patients with smaller tumours (less than $4 \mathrm{~cm}$ ) with CT2-3 N0-1 stage, with at most limited nodal disease at diagnosis. The present study included more locally advanced tumours at diagnosis.

A focus on the prevalence of lymph node metastases is particularly relevant when organ preservation is being contemplated. With all organ-preserving strategies (including local scar excision) the regional lymph nodes are left in situ and are a potential source of recurrence. Although it is often stated that the risk of leaving involved nodes behind is small for ypT0-1 tumours and too high for ypT2 tumours, the differences were not that marked in the present study $(7,12$, and 17 per cent for ypT0, ypT1, and ypT2 respectively). The prevalence of 40 per cent for ypT3 tumours was substantially higher. Whether or not to consider organ preservation or to undertake TME is reliant on a risk-benefit assessment that should include information from baseline and post-treatment staging, histology if local excision was performed, and also patient preference and co-morbidity.

It is also interesting to note that in a pooled analysis of 880 patients with a clinical complete response managed according to a watch-and-wait strategy, only 11 patients had nodal regrowth ${ }^{3}$. This is much lower than would be expected from the present findings. There are a number of possible reasons for this. Not all lymph node metastases detected by the pathologist in the TME specimen 6-8 weeks after irradiation may represent viable tumour, and the longer interval between restaging and the decision to watch and wait may allow further regression ${ }^{34}$. Residual macrometastases in nodes are associated with a poor prognosis. However, small residual micrometastases found in the nodes at histopathology 6-8 weeks after chemoradiotherapy might regress if a longer interval is applied, and may not be of clinical significance (62 per cent ypNO within 4-8 weeks versus 73 per cent ypNO within $8-12$ weeks) ${ }^{35,36}$. ypT category is also a crude measure of response to chemoradiotherapy that does not correlate directly with tumour volume. Patients who have an apparently (near) complete response at restaging (MRI and endoscopy) but actually have a small ypT2 remnant that becomes obvious with follow-up could have a lower proportion of lymph node metastases than patients with a moderate response and a large remaining ypT2 tumour. Finally, although still controversial in early disease ${ }^{37}$, MRI has improved local staging, so patients with obvious lymph node metastases on imaging are not selected for organ preservation and undergo formal TME, which reduces the risk of nodal regrowth. In addition to yp $\mathrm{T}$ category, there are other histological 

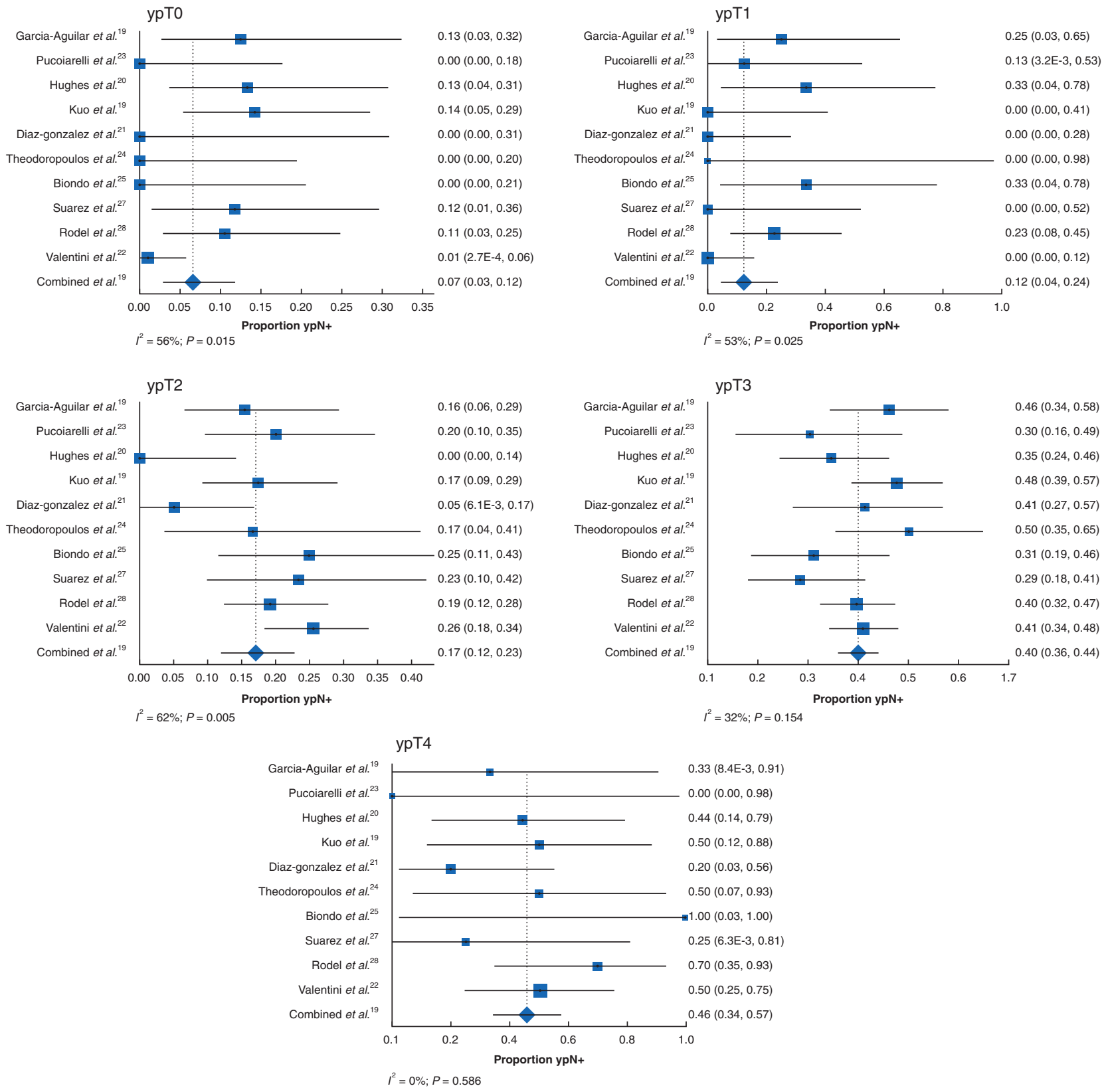

Fig. 1 Pooled proportions of ypN + disease by ypT category

a ypT0, b ypT1, с ypT2, d ypT3, and e ypT0. A random-effects model was used for meta-analysis. Proportions are shown with 95 per cent intervals. Heterogeneity is indicated by the $I^{2}$ value.

Table 2 Proportion of patients with positive lymph nodes according to (y)pT category after chemoradiation in the present study compared with results reported in the literature for patients not treated with neoadjuvant chemoradiotherapy

ypN + rate (\%)

After chemoradiotherapy (present study)

Without neoadjuvant treatment (published studies)

\begin{tabular}{lll}
\hline (y)pT0 & 7 & \\
(y)pT1 & 12 & $6-14^{8-14}$ \\
(y)pT2 & 17 & $17-23^{8-14}$ \\
(y)pT3 & 40 & $49-66^{8,13}$ \\
(y)pT4 & 46 & $50-79^{8,13}$ \\
\hline
\end{tabular}

parameters by which to identify patients at a higher risk of lymph node metastases who are less suitable for organ-preserving treatment, such as lymphatic or vascular invasion and differentiation grade $^{38,39}$. As differentiation grade and other histopathological factors of the tumour were poorly recorded in this pooled data set, these factors could not be included in the analyses.

It has been suggested that adjuvant therapy could improve oncological outcome in patients with lymph node metastases. However, a meta-analysis ${ }^{40}$ found that patients with rectal cancer did not benefit from adjuvant chemotherapy with regard to DFS (HR 0.91, 95 per cent c.i. 0.77 to $1.07 ; P=0.230$ ) and distant recurrence (HR 0.94, 0.78 to 1.14; $\mathrm{P}=0.523$ ) compared with observation. In the present study, $\mathrm{cN}$ category lacked predictive value for survival outcomes. This was probably related to the low 
a

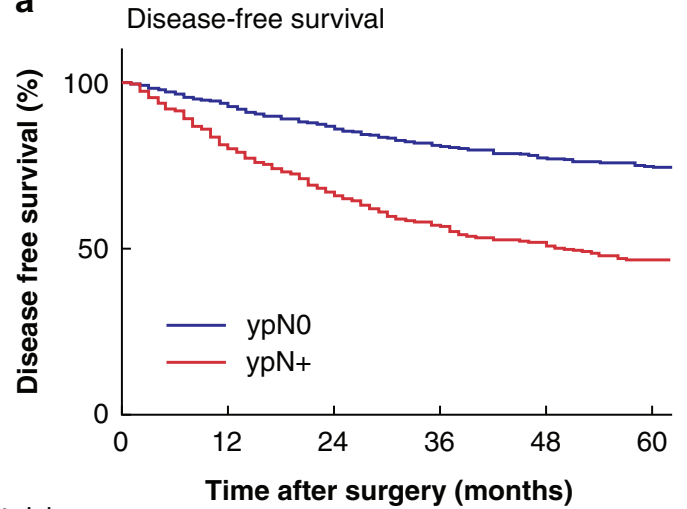

No. at risk

$\begin{array}{ccccccc}\text { ypNo } & 1343 & 1196 & 1014 & 827 & 666 & 522 \\ \text { ypN+ } & 509 & 391 & 295 & 217 & 161 & 123\end{array}$

b

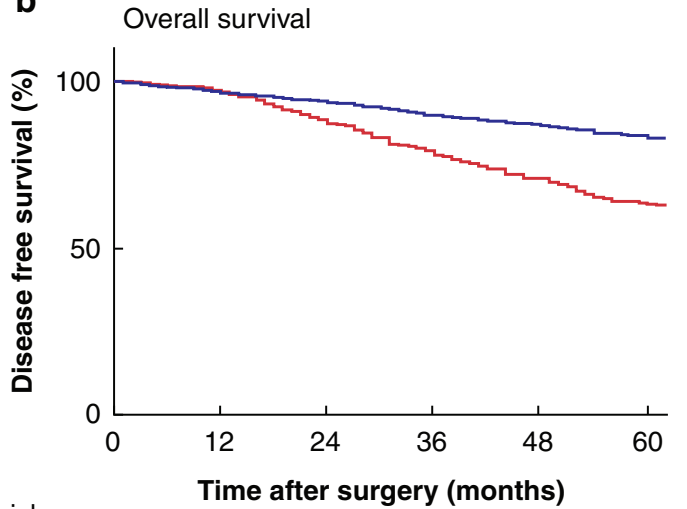

No. at risk

$\begin{array}{lcccccc}\text { ypNo } & 1347 & 1244 & 1100 & 912 & 741 & 589 \\ \text { ypN+ } & 509 & 468 & 379 & 285 & 216 & 165\end{array}$

Fig. 2 Survival curves by ypN status for the total patient group

a Disease-free survival and $\mathbf{b}$ overall survival. a,b $\mathrm{P}<0.001$ (log rank test).

Table 3 Adjusted hazard ratios from multivariable Cox proportional hazards models for patients with ypT0-2 disease stratified by data set

\begin{tabular}{|c|c|c|}
\hline & \multicolumn{2}{|c|}{ Hazard ratio } \\
\hline \multicolumn{3}{|l|}{ Sex } \\
\hline $\mathrm{F}$ & $0.84(0.61,1.17)$ & $0.73(0.49,1.11)$ \\
\hline Age (per year) & $1.00(0.99,1.01)$ & $1.00(0.99,1.02)$ \\
\hline \multicolumn{3}{|c|}{ Clinical tumour category at baseline } \\
\hline сT3 & 1.00 (reference) & 1.00 (reference) \\
\hline cT4 & $1.88(1.20,2.97)$ & $1.58(0.92,2.74)$ \\
\hline \multicolumn{3}{|c|}{ Clinical node category at baseline } \\
\hline $\mathrm{cNO}$ & 1.00 (reference) & 1.00 (reference) \\
\hline $\mathrm{cN}+$ & $0.94(0.67,1.35)$ & $1.14(0.76,1.73)$ \\
\hline \multicolumn{3}{|c|}{ Distance from anal verge $(\mathrm{cm})$} \\
\hline$\leq 5$ & 1.00 (reference) & 1.00 (reference) \\
\hline \multicolumn{3}{|l|}{ Type of surgery } \\
\hline \multicolumn{3}{|c|}{ Pathological T category } \\
\hline pTO & 1.00 (reference) & 1.00 (reference) \\
\hline pT1 & $0.75(0.42,1.36)$ & $0.77(0.40,1.48)$ \\
\hline pT2 & $1.10(0.77,1.58)$ & $0.84(0.56,1.28)$ \\
\hline \multicolumn{3}{|c|}{ Pathological N category } \\
\hline pNO & 1.00 (reference) & 1.00 (reference) \\
\hline $\mathrm{pN}+$ & $2.45(1.70,3.54)$ & $2.05(1.28,3.29)$ \\
\hline \multicolumn{3}{|c|}{ Adjuvant chemotherapy } \\
\hline No & 1.00 (reference) & 1.00 (reference) \\
\hline Yes & $0.64(0.44,0.96)$ & $0.49(0.30,0.81)$ \\
\hline
\end{tabular}

Values in parentheses are 95 per cent confidence intervals; LAR, low anterior resection; APR, abdominal perineal resection. A hazard ratio below 1 indicates a lower probability of an unfavourable event.

accuracy of clinical nodal staging, which was mainly performed with endorectal ultrasonography and CT. Currently, MRI is the recommended modality for assessment of node status; however, T2-weighted MRI also only yields a moderate sensitivity and specificity of 77 and 60 per cent respectively. The per-lesion sensitivity for nodal staging after chemoradiotherapy is 91 per cent, indicating a low rate of false-negative findings when staging individual mesorectal nodes ${ }^{41}$. Lahaye and colleagues ${ }^{42}$ reported sensitivities of up to 85 per cent for nodal staging with T2- weighted MRI after chemoradiotherapy based on size criteria, further confirming the low risk of missing lymph node metastases. Nevertheless, given the 17 per cent prevalence of lymph node metastases in ypT2 disease, physicians should remain alert to the possible presence of lymph node metastases in patients with substantial downstaging of the primary rectal cancer.

This study has several limitations. Data were retrieved from a subset of individual studies with a heterogeneous patient population and differences between studies. Some of the studies were 
Table 4 Adjusted hazard ratios from multivariable Cox proportional hazards models for the total cohort stratified by data set

\begin{tabular}{|c|c|c|}
\hline & \multicolumn{2}{|c|}{ Hazard ratio } \\
\hline \multicolumn{3}{|l|}{ Sex } \\
\hline $\mathrm{F}$ & $0.84(0.70,1.01)$ & $0.81(0.65,1.02)$ \\
\hline Age (per year) & $0.99(0.98,1.00)$ & $0.99(0.99,1.01)$ \\
\hline \multicolumn{3}{|c|}{ Clinical tumour category at baseline } \\
\hline cT4 & $1.33(1.04,1.72)$ & $1.23(0.92,1.67)$ \\
\hline \multicolumn{3}{|c|}{ Clinical node category at baseline } \\
\hline CNO & 1.00 (reference) & 1.00 (reference) \\
\hline $\mathrm{cN}+$ & $1.03(0.84,1.28)$ & $1.20(0.94,1.54)$ \\
\hline \multicolumn{3}{|c|}{ Distance from anal verge $(\mathrm{cm})$} \\
\hline$\leq 5$ & 1.00 (reference) & 1.00 (reference) \\
\hline \multicolumn{3}{|c|}{ Pathological T category } \\
\hline pT0 & 1.00 (reference) & 1.00 (reference) \\
\hline pT1 & $0.85(0.48,1.51)$ & $0.82(0.44,1.57)$ \\
\hline pT2 & $1.15(0.82,1.63)$ & $0.85(0.57,1.28)$ \\
\hline pT3 & $2.01(1.46,2.77)$ & $1.62(1.13,2.33)$ \\
\hline pT4 & $2.89(1.77,4.74)$ & $2.37(1.37,4.11)$ \\
\hline \multicolumn{3}{|c|}{ Pathological N category } \\
\hline pNO & 1.00 (reference) & 1.00 (reference) \\
\hline $\mathrm{pN}+$ & $2.26(1.87,2.74)$ & $2.08(1.66,2.62)$ \\
\hline \multicolumn{3}{|c|}{ Adjuvant chemotherapy } \\
\hline No & 1.00 (reference) & 1.00 (reference) \\
\hline Yes & $0.61(0.49,0.76)$ & $0.51(0.40,0.68)$ \\
\hline
\end{tabular}

Values in parentheses are 95 per cent confidence intervals; LAR, low anterior resection; APR, abdominal perineal resection. A hazard ratio below 1 indicates a lower probability of an unfavourable event.

retrospective. However, a random-effects model was used to take heterogeneity into account when pooling the proportions of lymph node metastases by ypT category, and Cox proportional hazards analyses with stratification by data set were used to evaluate long-term outcome. Because of missing data, not all patients could be included in all analyses. Additionally, some baseline and histopathological details were lacking, such as the presence of tumour deposits, extramural vascular invasion, completeness of resection, size and number of harvested and involved nodes, and size and exact location of residual tumour in the bowel wall; this information could be of help in interpreting the data ${ }^{39,40,43}$. Moreover, clinical staging was probably suboptimal (specifically for nodal status) as MRI was not used in most studies, which may have influenced the outcomes. Finally, this pooled analysis was based on historical studies published between 2002 and 2008. However, this provided a unique opportunity to evaluate lymph node metastases in patients with rectal cancer who receive chemoradiotherapy and all undergo surgery, in contrast to current cohorts in which organ preservation is increasingly being offered.

\section{Acknowledgements}

J. Garcia-Aguilar's work on this study was funded in part by grant P30 CA008748 from the National Cancer Institute.

Disclosure. The authors declare no conflict of interest.

\section{Supplementary material}

Supplementary material is available at BJS online.

\section{References}

1. Heald RJ, Ryall RD. Recurrence and survival after total mesorectal excision for rectal cancer. Lancet 1986;1:1479-1482

2. Sauer R, Becker H, Hohenberger W, Rödel C, Wittekind C, Fietkau R et al. Preoperative versus postoperative chemoradiotherapy for rectal cancer. N Engl J Med 2004;351:1731-1740

3. van der Valk MJM, Hilling DE, Bastiaannet E, Meershoek-Klein Kranenbarg E, Beets GL, Figueiredo NL et al. Long-term outcomes of clinical complete responders after neoadjuvant treatment for rectal cancer in the International Watch \& Wait Database (IWWD): an international multicentre registry study. Lancet 2018;391:2537-2545

4. Dossa F, Chesney TR, Acuna SA, Baxter NN. A watch-and-wait approach for locally advanced rectal cancer after a clinical complete response following neoadjuvant chemoradiation: a systematic review and meta-analysis. Lancet Gastroenterol Hepatol 2017;2:501-513

5. Dattani M, Heald RJ, Goussous G, Broadhurst J, Sao JG, HabrGama A. Oncological and survival outcomes in watch and wait patients with a clinical complete response after neoadjuvant chemoradiotherapy for rectal cancer: a systematic review and pooled analysis. Ann Surg 2018;268:955-967

6. Rullier E, Vendrely V, Asselineau J, Rouanet P, Tuech JJ, Valverde A et al. Organ preservation with chemoradiotherapy plus local 
excision for rectal cancer: 5-year results of the GRECCAR 2 randomised trial. Lancet Gastroenterol Hepatol 2020;5:465-474

7. Borschitz T, Wachtlin D, Mohler M, Schmidberger H, Junginger T. Neoadjuvant chemoradiation and local excision for T2-3 rectal cancer. Ann Surg Oncol 2008;15:712-720

8. Ricciardi R, Madoff RD, Rothenberger DA, Baxter NN. Population-based analyses of lymph node metastases in colorectal cancer. Clin Gastroenterol Hepatol 2006;4:1522-1527

9. Blumberg D, Paty PB, Guillem JG, Picon AI, Minsky BD, Wong WD et al. All patients with small intramural rectal cancers are at risk for lymph node metastasis. Dis Colon Rectum 1999;42:881-885

10. Fang WL, Chang SC, Lin JK, Wang HS, Yang SH, Jiang JK et al. Metastatic potential in T1 and T2 colorectal cancer. Hepatogastroenterology 2005;52:1688-1691

11. Stornes T, Wibe A, Nesbakken A, Myklebust T, Endreseth BH. National early rectal cancer treatment revisited. Dis Colon Rectum 2016;59:623-629

12. Rasheed S, Bowley DM, Aziz O, Tekkis PP, Sadat AE, Guenther T et al. Can depth of tumour invasion predict lymph node positivity in patients undergoing resection for early rectal cancer? A comparative study between T1 and T2 cancers. Colorectal Dis 2008;10:231-238

13. Sitzler PJ, Seow-Choen F, Ho YH, Leong AP. Lymph node involvement and tumor depth in rectal cancers: an analysis of 805 patients. Dis Colon Rectum 1997;40:1472-1476

14. Yamamoto S, Watanabe M, Hasegawa H, Baba H, Yoshinare K, Shiraishi J et al. The risk of lymph node metastasis in T1 colorectal carcinoma. Hepatogastroenterology 2004;51:998-1000

15. Nagtegaal ID, Marijnen CAM. The future of TNM staging in rectal cancer: the era of neoadjuvant therapy. Curr Colorectal Cancer Rep 2008;4:147-154

16. Mignanelli ED, de Campos-Lobato LF, Stocchi L, Lavery IC, Dietz DW. Downstaging after chemoradiotherapy for locally advanced rectal cancer: is there more (tumor) than meets the eye? Dis Colon Rectum 2010;53:251-256

17. Rullier E, Rouanet P, Tuech JJ, Valverde A, Lelong B, Rivoire M et al. Organ preservation for rectal cancer (GRECCAR 2): a prospective, randomised, open-label, multicentre, phase 3 trial. Lancet 2017;390:469-479

18. Maas M, Nelemans PJ, Valentini V, Das P, Rodel C, Kuo LJ et al. Long-term outcome in patients with a pathological complete response after chemoradiation for rectal cancer: a pooled analysis of individual patient data. Lancet Oncol 2010;11:835-844

19. García-Aguilar J, Hernandez de Anda E, Sirivongs P, Lee SH, Madoff RD, Rothenberger DA. A pathologic complete response to preoperative chemoradiation is associated with lower local recurrence and improved survival in rectal cancer patients treated by mesorectal excision. Dis Colon Rectum 2003;46:298-304

20. Hughes R, Glynne-Jones R, Grainger J, Richman P, Makris A, Harrison $\mathrm{M}$ et al. Can pathological complete response in the primary tumour following pre-operative pelvic chemoradiotherapy for T3-T4 rectal cancer predict for sterilisation of pelvic lymph nodes, a low risk of local recurrence and the appropriateness of local excision? Int J Colorectal Dis 2006;21:11-17

21. Díaz-González JA, Calvo FA, Cortés J, García-Sabrido JL, GómezEspí M, Del Valle E et al. Prognostic factors for disease-free survival in patients with T3-4 or $\mathrm{N}+$ rectal cancer treated with preoperative chemoradiation therapy, surgery, and intraoperative irradiation. Int J Radiat Oncol Biol Phys 2006;64:1122-1128

22. Valentini V, Coco C, Picciocchi A, Morganti AG, Trodella L, Ciabattoni A et al. Does downstaging predict improved outcome after preoperative chemoradiation for extraperitoneal locally advanced rectal cancer? A long-term analysis of 165 patients. Int J Radiat Oncol Biol Phys 2002;53:664-674

23. Pucciarelli S, Toppan P, Friso ML, Russo V, Pasetto L, Urso E et al. Complete pathologic response following preoperative chemoradiation therapy for middle to lower rectal cancer is not a prognostic factor for a better outcome. Dis Colon Rectum 2004;47: 1798-1807

24. Theodoropoulos G, Wise WE, Padmanabhan A, Kerner BA, Taylor CW, Aguilar PS et al. T-level downstaging and complete pathologic response after preoperative chemoradiation for advanced rectal cancer result in decreased recurrence and improved disease-free survival. Dis Colon Rectum 2002;45:895-903

25. Biondo S, Navarro M, Marti-Rague J, Arriola E, Pares D, Del Rio C et al. Response to neoadjuvant therapy for rectal cancer: influence on long-term results. Colorectal Dis 2005;7:472-479

26. Kuo LJ, Liu MC, Jian JJ, Horng CF, Cheng TI, Chen CM et al. Is final TNM staging a predictor for survival in locally advanced rectal cancer after preoperative chemoradiation therapy? Ann Surg Oncol 2007; 14:2766-2772

27. Suárez J, Vera R, Balén E, Gómez M, Arias F, Lera JM et al. Pathologic response assessed by Mandard grade is a better prognostic factor than down staging for disease-free survival after preoperative radiochemotherapy for advanced rectal cancer. Colorectal Dis 2008;10:563-568

28. Rödel C, Martus P, Papadoupolos T, Füzesi L, Klimpfinger M, Fietkau $R$ et al. Prognostic significance of tumor regression after preoperative chemoradiotherapy for rectal cancer. J Clin Oncol 2005;23:8688-8696

29. Nyaga VN, Arbyn M, Aerts M. Metaprop: a Stata command to perform meta-analysis of binomial data. Arch Public Health 2014; 72:39

30. DerSimonian R, Laird N. Meta-analysis in clinical trials. Controlled Clinical Trials 1986;7:177-188

31. Higgins JPT, Thomas J, Chandler J, Cumpston M, Li T, Page MJ et al. Cochrane Handbook for Systematic Reviews of Interventions. https:// www.training.cochrane.org/handbook (accessed 20 July 2020)

32. Erkan A, Mendez A, Trepanier M, Kelly J, Nassif G, Albert MR et al. Impact of residual nodal involvement after complete tumor response in patients undergoing neoadjuvant (chemo)radiotherapy for rectal cancer. Surgery 2019;166:648-654

33. Duchalais E, Glyn Mullaney T, Spears GM, Kelley SR, Mathis K, Harmsen WS et al. Prognostic value of pathological node status after neoadjuvant radiotherapy for rectal cancer. Br J Surg 2018; 105:1501-1509

34. Calvo FA, Morillo V, Santos M, Serrano J, Gomez-Espí M, Rodriguez $\mathrm{M}$ et al. Interval between neoadjuvant treatment and definitive surgery in locally advanced rectal cancer: impact on response and oncologic outcomes. J Cancer Res Clin Oncol 2014; 140:1651-1660

35. Ryan ÉJ, O'Sullivan DP, Kelly ME, Syed AZ, Neary PC, O'Connell PR et al. Meta-analysis of the effect of extending the interval after long-course chemoradiotherapy before surgery in locally advanced rectal cancer. Br J Surg 2019;106:1298-1310

36. Akgun E, Caliskan C, Bozbiyik O, Yoldas T, Sezak M, Ozkok S et al. Randomized clinical trial of short or long interval between neoadjuvant chemoradiotherapy and surgery for rectal cancer. BrJ Surg 2018;105:1417-1425

37. Detering R, van Oostendorp SE, Meyer VM, van Dieren S, Bos A, Dekker JWT et al. MRI CT1-2 rectal cancer staging accuracy: a population-based study. BrJ Surg 2020;107:1372-1382

38. Smith FM, Chang KH, Sheahan K, Hyland J, O'Connell PR, Winter DC. The surgical significance of residual mucosal 
abnormalities in rectal cancer following neoadjuvant chemoradiotherapy. Br J Surg 2012;99:993-1001

39. Bosch SL, Vermeer TA, West NP, Swellengrebel HA, Marijnen CA, Cats A et al. Clinicopathological characteristics predict lymph node metastases in ypT0-2 rectal cancer after chemoradiotherapy. Histopathology 2016;69:839-848

40. Breugom AJ, Swets M, Bosset JF, Collette L, Sainato A, Cionini L et al. Adjuvant chemotherapy after preoperative (chemo)radiotherapy and surgery for patients with rectal cancer: a systematic review and meta-analysis of individual patient data. Lancet Oncol 2015;16:200-207

41. van der Paardt MP, Zagers MB, Beets-Tan RG, Stoker J, Bipat S. Patients who undergo preoperative chemoradiotherapy for locally advanced rectal cancer restaged by using diagnostic MR imaging: a systematic review and meta-analysis. Radiology 2013;269: 101-112

42. Lahaye MJ, Beets GL, Engelen SM, Kessels AG, de Bruïne AP, Kwee HW et al. Locally advanced rectal cancer: MR imaging for restaging after neoadjuvant radiation therapy with concomitant chemotherapy. Part II. What are the criteria to predict involved lymph nodes? Radiology 2009;252:81-91

43. Nougaret S, Castan F, de Forges H, Vargas HA, Gallix B, Gourgou $S$ et al. Early MRI predictors of disease-free survival in locally advanced rectal cancer from the GRECCAR 4 trial. Br J Surg 2019; 106:1530-1541 